\title{
The Determinants of Rental Rates and Selling Prices of Office Spaces in Jakarta: A Macroeconometric Model Using VECM Approach
}

\author{
Zainal Zawir Simon ${ }^{1}$, Noer Azam Achsani ${ }^{2}$, Adler H. Manurung ${ }^{2}$ \& Roy Sembel ${ }^{2}$ \\ ${ }^{1}$ Economic Faculty-YARSI University, Jakarta, Indonesia \\ ${ }^{2}$ Graduate Study in Business Management, Bogor Agricultural University, Bogor, Indonesia \\ Correspondence: Zainal Zawir Simon, Economic Faculty-YARSI University, Jl. Letjen Suprapto, Cempaka Putih, \\ Jakarta-10510, Indonesia. Tel: 62-21-426-9289. E-mail: zainalzawirsimon@yahoo.com
}

Received: December 9, 2014

Accepted: January 9, 2015

Online Published: February 25, 2015

doi:10.5539/ijef.v7n3p165

URL: http://dx.doi.org/10.5539/ijef.v7n3p165

\begin{abstract}
This paper empirically examines the macroeconomic factors that affect the rental rates and selling prices of office space. The data are in the form of quarterly time series which are used for the period of 1996: 1 to 2012: 4 period. In addition, quantitative methods in the form of Vector Error Correction Model (VECM) are also used in this study. The results showed that there is a long-term relationship between macroeconomic variables with the rental rate and selling prices of office space. IRF and FEVD showed that the rental rates and selling prices responded permanently to the shocks that occured on macroeconomic variables. Moreover, the rental rate is predominantly influenced by the rental rate followed by the service sector employment, the selling price, exchange rate, inflation, interest rates and economic growth. Conversely, the selling price is predominantly influenced by the rental rate followed by service sector employment, the exchange rate, economic growth, the selling price, infllation and interest rates. Investors and developers can use the results of this study as one of approaches of market analysis, especially for office market analysis.
\end{abstract}

Keywords: macroeconomic variables, rental rate, selling price, VAR / VECM

\section{Introduction}

An investment constitutes an effort that is undertaken by investor to invest money with the intention of making profit in the future. Investors may put their money into many instruments such as stock, bond, mutual fund, gold, real estate and bank deposit. Investment in real estate is considered as a long term investment compared to other types of investment. Investors may invest in income producing property and non-income producing property. When investing in income producing property, investors expect to get profit from income stream which is reflected in cashflow during the holding periods or ownership. Investors must stipulate the value of the properties they will buy and determine how much profit can be generated.

In determining income stream, investors must understand rental value. Investment properties should generate income which usually comes in the form of rent. Failure to determine rent as the source of income will result in a big loss or disappoinment for the investors. Investors must be able to analyze and predict the value of rental property. To do so, for the first stage investors should be able to understand what factors contribute to rental value. Similar situation also take place to investor in forming selling price of a property or office space. In determining selling price, investors should be able to understand factors that contribute to or affect property price.

Unlike the stock and bond sectors which have a lot of concern, there were only few empirical studies have been done regarding the factors which affect the performance of the property market (Kurzrock et al., 2009). Furthermore, there were no relevant research results found in Southeast Asian countries (Chin, 2003). Most studies of property market are only focused in the United States, Europe and United Kingdom. If there were, only little attention given to the countries in Southeast Asia ( $\mathrm{Ng} \&$ Higgins, 2006).

On the real estate field, the market analysis is a final outcome of the investigation and documentation regarding with several factors that determine the demand for a certain type of real estate, the number of real estate deals and the boundaries of geography of the trade area (Thrall, 2002). Therefore it is important to understand the various of existing characteristics for different types of real estate. Analysis of the real estate market studies the 
factors that contribute to the supply and demand of a particular type of real estates.

Research that has been done regarding with the determinants in both of the rental rate and selling prices of office space can be categorized into 'issues of macroeconomic and microeconomic (Slade, 2000). Various studies which have been conducted in this area have an effect option for variable supply and demand as a proxy in an effort to predict the performance of office market. Office rental rates can become a model by using the framework of the theory of demand and supply. Rental rates can be determined by the interaction between the the demand and supply which affecting the office space rental market (Chin, 2003).

Thus, it can be said that macroeconomic factors are equal to demand factors, whereas, the microeconomic factors are equal to supply factors. Macroeconomic factors or demand consist of economic growth (GDP), interest rates, employment, unemployment, inflation, income, population, taxation and others. While the microeconomic factors or offers include, vacancy rates, office space inventory (Stock), absorption rate, occupancy rate, the cost of construction and physical characteristics as well as others from the property. The supply factors and demand will eventually have an impact on the rental rate and selling prices for office space market.

There is a lot of research that have been done regarding with the econometric model and determinants for office rental rates. It is conducted in various areas in the United States and several research centers in Europe and UK (see e.g., Oven \& Pekdemir, 2006; Chin, 2003; Chalermpong \& Wattana, 2009). But unfortunately, little attention has been given to countries in Southeast Asia (Ng \& Higgins, 2006).

Many studies have been conducted with regard to the modeling of rental rates which were influenced by various macroeconomic factors or requests, such as GDP, inflation, interest rates, employment services sector, and the unemployment rate. Chin (2003), in the study of macro-economic factors which affect the price of the rental office in Southeast Asia (Indonesia not included) discovered variable that was used such as GDP, interest rates, loan interest rates, consumer price index (inflation), the output services, unemployment which have been associated with the same changes in rental rate and there was a little of difference.

For Singapore, there are variables that give significant effect. For Hong Kong, the influence are in the form of the services sector output. For Taipei, factors that being influence are in the form of the supply of office space, the unemployment rate, and the output of the service sector. For Kuala Lumpur, the significant influence are in the form of GDP, unemployment, interest rates on loans, consumer price index, and the output of the service sector. Whereas for Bangkok, the significant influence are in the form of interest rate and the output of the service sector. Meanwhile, De Wit and Van Dijk (2003) found that GDP, unemployment and inflation have a significant relationship to the selling price. GDP is positively related to rental rates, and the unemployment rate is negatively related to rental rates.

For labor in Germany, Voigtlander (2011) found that office worker is the best predictor to determine the average of rental rates in comparison with the overall level of employment and unemployment. Brounen and Jennen (2009) found that the rental rates in all 15 cities in the United States would respond to the increase in the level of workers of office. The increase in the level of employment is positively associated with office rental rates.

Tsolacos et al. (1998) found that the demand factors (GDP, interest rates and unemployment rate) has a significant influence on the establishment of the rental rates for office buildings. Oven and Pakdemir (2006) also found that interest rate is one of the important factors in determining rental rates of office in Istanbul.

A study conducted by D'Arch et al. (1999) found the relationship between GDP with rental rates, where the change in GDP is one of the most dominant factor to affect the rental rates. While Ng and Higgins (2006) found some macroeconomic variables such as interest rates and employment on services sector were factors that affects the rental rates in the central region of Singapore. However, previous studies conducted by Dobson and Goddard (1992) found that interest rate has a negative correlation to the real estate industry and offices, whereas the rental rates has a positive relationship to all types of real estates.

Hong Kong has been recognized as an international financial center and it is characterized by many entries of foreign companies which expand its business. Therefore, the Hong Kong economy is strongly influenced by globalization and macroeconomic factors. The results of an empirical study conducted by Prudence (2007) showed that in general, the rental market for office space of class A and B were significantly influenced by globalization, including foreign direct investment and total exports. While the building of $\mathrm{C}$ class is more influenced by the local economy such as GDP.

Not only the rental rate, the macroeconomic variables also could affect the selling price of office buildings. Singh and Komal (2009) in their study in India found that the GDP, inflation and interest rates could affect the selling price of real estate in India. When the GDP increases, the price is also increased. So it can be said that 
there is a strong positive correlation between real estate prices and GDP. Likewise, the price of real estate will rise if the inflation and interest rates are increased.

The real estate market has an important role in the economy of Hong Kong. Changes in real estate prices can affect other parts of the economy through a variety of channels. The increase in real estate prices have a negative effect on consumption, because the savings must be increased in order to be able to pay a deposit which is more costly. In contrast, the decline in real estate prices could encourage consumption because of the decreasing of advance payment. A decline in rate of real estate prices could reduce real GDP by $1.25 \%$ (Peng et al., 2001).

Other factors that have an influence on the selling price is labor. The changes of employment will have a positive influence on selling prices and rental rates (Dobson \& Goddard, 1992). Meanwhile De Wit and Van Dijk (2003) in their study found that the GDP and inflation has a positive relationship with price changes. Meanwhile, unemployment rate has a negative correlation to change the price of real estate.

A number of previous studies have been conducted with regard to the effect of exchange rate with stocks or bonds, as practiced by Ajayi and Mougoue (1996), and Dimitrova (2005). In contrast, only a few studies that examine the relationship between exchange rate with the rental rates or sale price of real estate. Xiuzhing and Xiaoguang (2006) conducted research on the effect of exchange rate and real estate prices in China. Research results showed that if the condition of a country's currency value is getting better, the sale price of real estate will be higher. In addition of that, it is also creating a price bubble. Such as in Taiwan, if the domestic currency value is improved, the real estate prices will rise. Reforms in the exchange rate also has led to fluctuations on the price of real estate.

In Malaysia, Shaifulfazlee (2012) also conducted a study using an exchange rate and some other macroeconomic variables. Research results showed that inflation and the exchange rate affects the price of the property but not on GDP. The increasing of fluctuations of exchange rate affected by an open economic system in Malaysia. In this study, a positive relationship occurred between exchange rates and home prices. That way will led to a positive economic forecast for the future of Malaysia. Then investors will continue to invest on the property sector eventhough the price is a bit more expensive.

After carefully searching for the information about similar research, there is no related result found in Indonesia. Therefore, it is hoped that this research result will have a contribution to practitioners in commercial property market, especially office space market in Jakarta.

Based on the explanation above, the objectives of the study was to assess the influence and behavior of macroeconomic factors or demand side, such as economic growth, inflation, interest rates, service sector employment, unemployment and the exchange rate toward the rental rate and selling prices of office space in Jakarta.

\section{The Data and Methodology}

The data used in this study are secondary data in the form of quarterly time series from the period 1996: 1 to 2012: 4. The variable used is the Gross Domestic Product (GDP), the Interest Rate (IntrRt), the level of inflation (InflRt), Exchange Rate (ExcRt), Employment Services Sector (SSEmp), Rental Rate (Rent) and the Selling Price (SIPrc). Data for variable Rent, SIPrc, IntrRt, ExcRt and GDP come from Bank Indonesia (BI), while variable SSEmp and InflRt sourced from the Central Statistics Agency (BPS). The original data that is not in the form of a percentage modified (normalized) with the logarithm, so that everything can be interpreted in terms of percent, except for the original data are already in the form of percent.

The method used in this research was a vector autoregression (VAR) introduced by Sims which describes a causal relationship between variables in the system followed by a VECM. It aimed to be able to get a picture of the short and long-term relationships of the variables in the study. If the data used stationary at first difference, the VAR will be combined with the error correction mode thus becoming a Vector Error Correction Model (VECM). Before obtaining the estimation of the VECM, a variety of tests should be through including the unit root test, stability test, the optimal lag test and cointegration test.

According to Ward and Siregar (2000), VECM model which generally used in the study are as follows:

$$
\Delta y_{t}=\sum_{i=1}^{k-1} \Gamma_{i} \Delta y_{t-1}+\mu_{0}+\mu_{t} t+\alpha \beta^{\prime} y_{t-1}+\varepsilon_{t}
$$

Where $\Delta \mathrm{yt}=\mathrm{yt}-\mathrm{yt}-1,(\mathrm{k}-1)=\mathrm{VECM}$ ordo fromVAR, $\Gamma \mathrm{i}=$ regression coefficient matrices; $\mu_{0}=$ intercept vector, $\mu_{1}=$ regression coefficient vector, $\mathrm{a}=$ loading matrix; $\beta$ '= cointegration vector, and $\mathrm{yt}=$ variable in level.

Thereby equation model of VAR / VECM for rental rates and selling prices of office space are as follows: 


$$
\begin{aligned}
& \text { LRent }_{t}=a_{1}+\sum_{i=\frac{1}{P}}^{P} b_{1 i} \text { LRent }_{t-i}+\sum_{i=1}^{P} c_{1 i} \text { LSLPr }_{t-i}+\sum_{i=1}^{P} d_{1 i} \text { IntrRt }_{t-i}+\sum_{i=1}^{P} e_{1 i} \text { LInflRt }_{t-i} \\
& \begin{aligned}
& +\sum_{i=1}^{P} f_{1 i} \text { LGDP }_{t-i}+\sum_{i=1}^{P} g_{1 i} \text { LSSEmp }_{t-i}+\sum_{i=1}^{P} h_{1 i} \text { UnEmp }_{t-i}+\sum_{i=1}^{P} i_{1 i} \text { LExcRt }_{t-i}+u_{1 t} \\
\text { LSIPrc }_{t}=a_{2}+ & \sum_{i=1}^{P} b_{2 i} \text { LRent }_{t-i}+\sum_{i=1}^{P} c_{2 i} \text { LSLPrc }_{t-i}+\sum_{i=1}^{P} d_{2 i} \text { IntrRt }_{t-i}+\sum_{i=1}^{P} e_{2 i} \text { LInflRt }_{t-i} \\
& +\sum_{i=1}^{P} f_{2 i} \text { LGDP }_{t-i}+\sum_{i=1}^{P} g_{2 i} \text { LSSEmp }_{t-i}+\sum_{i=1}^{P} h_{2 i} \text { UnEmp }_{t-i}+\sum_{i=1}^{P} i_{2 i} L E x c R t_{t-i}+u_{2 t}
\end{aligned}
\end{aligned}
$$

Where Rent: Office Rent, SlPrc: Selling Price, IntrRt: Interest Rate, InflRt: Inflation Rate, GDP: Gross Domestic Product, SSEmp: Service Sector Employment, UnEmp: Unemployment, dan ExcRt: Exchange Rate.

\section{Result and Discussion}

\subsection{Development of Rental Rates and Selling Price for Office Space}

Property business in Indonesia, either for residential and commercial properties are getting upward. By 2012, in JABODEBEK (Jakarta, Bogor, Depok and Bekasi) the commercial property such as hotels, apartments, offices, retail and industrial land were experiencing a positive trend. It is supported by the improvement of economic growth, the increasing of demand, better financial support and more conducive government policies. All of them are expected to be able to encourage the development of the Indonesian property industry in the next few years, BI (2013). The rental rate development of the commercial property industry based on the results of a survey conducted by Bank Indonesia is shown in Figure 1 and Figure 2.

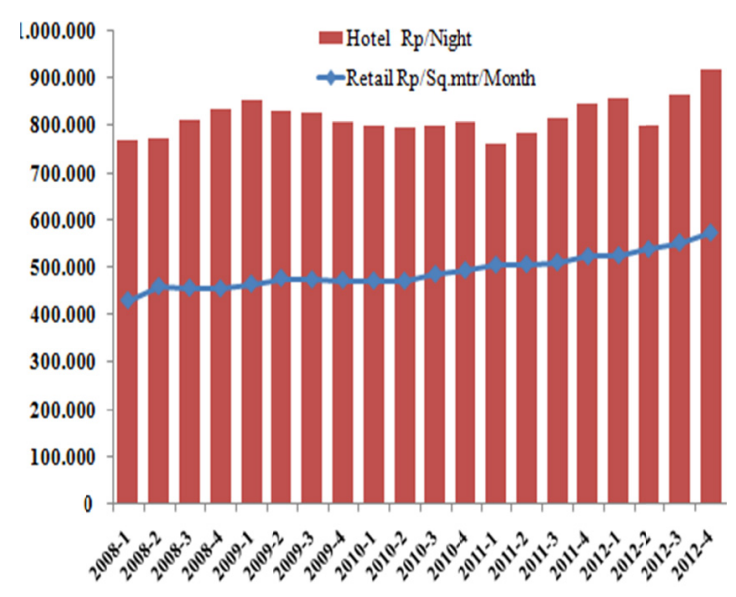

Figure 1. Rent of hotel and retail

Source: Commercial Property Survey - BI (2013).

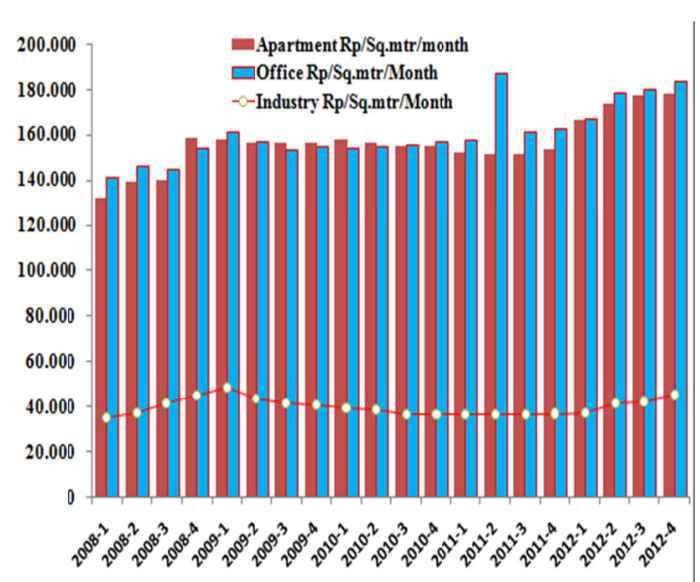

Figure 2. Rent of apartment, office and industry

Source: Commercial Property Survey - BI 2013). 
In the year of 2012 the amount of supplies of commercial property in Jabodebek have been increased, followed by an increase of demand in almost of commercial property types, such as retail, industrial and office land. But, in contrast, the retail sector are experiencing delay and recovered again after third quarter. The increase of the occupancy rate in almost of all commercial properties caused an increase in rental rates that also led to increase the sales of commercial property followed by the improvement in the sale price. Until the next few years, the commercial property growth in Jabodebek is expected to be increased.

Each type of properties and commercial real estate are different in term of development and the market. Hence, real estate market is the most unique if compared with the various forms of existing markets, such as the stock exchange, bonds and others. Similarly, factors that affect supply and demand in each types of real estates also have the differences.

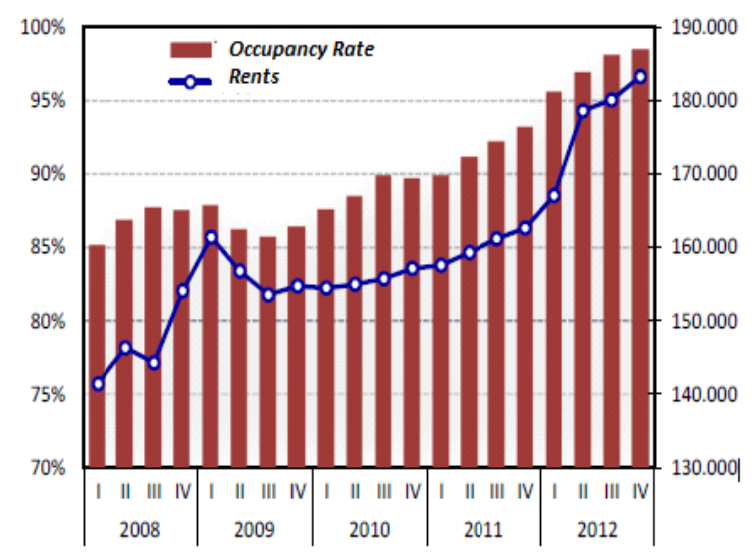

Figure 3. Rental rates of office spaces

Source: Commercial Property Survey-BI (2013).

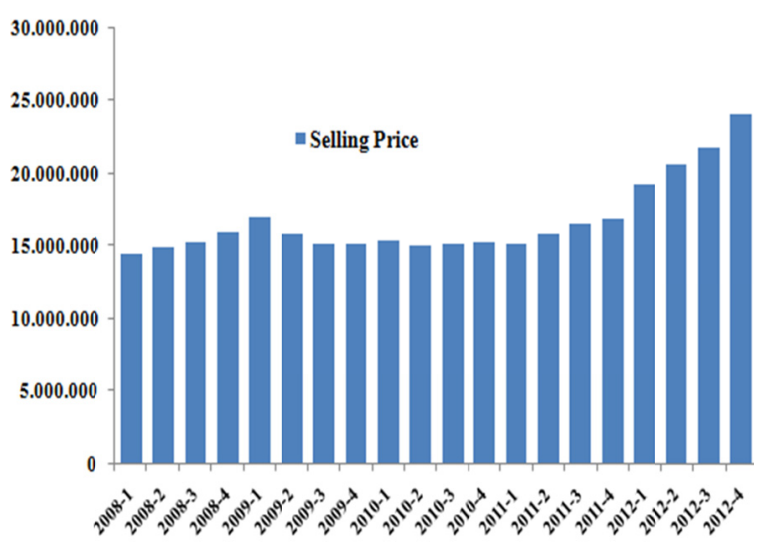

Figure 4. Selling price of office spaces

Source: Commercial Property Survey-BI (2013).

A survey has been conducted by Bank Indonesia regarding to the growth of real estate office buildings in Jakarta for the period of 2008-2012, as shown in Figure 3 and Figure 4. In general, the price of the rental office building appears to have increased, except for the first quarter of 2008 which were decreased and followed by a decrease of occupancy rate. The decline in the first quarter of 2008 was due to the unfavorable business environment and the state of the economy which is slowing and continued until the approaching period of 2009, Property Report (2009). For the first quarter of 2009, the occupancy rate and rental rate were increased and then significantly decreased either in occupancy rates, sale price and rental rates until the end of 2009.

By the following years until the end of 2012, the rental rate and selling prices experienced an increasing trend. The fluctuation of rental rates and the selling price of office space seemed influenced by many factors including, 
the exchange rate of US dollar, the price of fuel, economic growth, increasing of demand, relocation and expansion of the company and so forth. These factors are part of the survey conducted by Bank Indonesia.

The survey results above have described how the the rental rate and selling prices were influenced by various factors. However, it has not reflected the overall yet, especially the macroeconomic factors or demand and microeconomic factors or supply which can affect the selling price and the rental rate for the office space. In addition, it was also depending on the circumstances, there has been no study that discussed the macroeconomic or microeconomic factors and their influence on selling prices and the rental rate for office space in Jakarta.

\subsection{VECM Analysis for Rental Rate and Selling Price}

Before doing further analysis, first-related testing on VAR / VECM was conducted. The first test was a stasionarity test for time series of data which have a mean and fluctuating diversity, in order to avoid the problem of spurious regression. At the level, stasionarity test results may not seem stationary, except interest rates. This means that almost all of the data at level contain the root unit. Then, the testing at the level of the first difference was conducted. After first difference test, all the existing macroeconomic variables seemed to have been stationary or did not contain unit root (see Appendix A).

The next test is the stability test on VAR which were conducted by calculating the roots of a polynomial function or known as roots of the characteristic polynomial. If all roots of the polynomial function were in the unit circle or if the absolute value $<1$ then the VAR model is considered to be stable so that the Impulse Response Function (IRF) and Forecast Error Variance Decomposition (FEVD) which have generated considered into valid (see Table B1 and Figure B1 in appendix B).

Other testings that was used in the model is determining the optimum lag. The optimal lag length is determined using several criteria as follows: the Akaike Information Criterion (AIC), Schwarz Information Criterion (SC), Hannan-Quinn Criterion (HQ), Likelihood Ratio (LR), and Final Prediction Error (FPE). Optimum lag that used in this study were drawn from the SC by picking the smallest value. Therefore, lag 1 was used as optimim lag (see Table $\mathrm{C} 1$ in Appendix C).

The further step is a cointegration test which aimed to determine whether the variables are not stationary cointegrated or not. If the value of the trace statistic $>$ critical value, then the equation cointegrated. Thereby, $\mathrm{H}_{0}$ which was equal to non cointergration with alternative hypothesis was accepted $\mathrm{H}_{1}$ which was equal to cointegration. If the trace statistice > critical value, then reject $\mathrm{H}_{0}$ or accept $\mathrm{H}_{1}$, which considered to be cointegrated. On the value of the trace statistics, there were three cointegration rank in the model. This means that in this model, there were three cointegrating vector which can be concluded to three long-term linear equations in the model (see Table $\mathrm{C} 2$ in Appendix C). After passing various tests, the existing requirements on VAR system, then, continue to VECM estimation results.

Table 1. VECM estimate for rental rate

\begin{tabular}{|c|c|c|c|}
\hline \multicolumn{2}{|c|}{ Short Term } & \multicolumn{2}{|c|}{ Long Term } \\
\hline Variables & $\mathrm{D}$ (LRent) & Variables & LRent \\
\hline CointEq1 & -0.034423 & LRent(-1) & 1.000000 \\
\hline CointEq2 & $-0.348427^{*}$ & $L \operatorname{SlPrc}(-1)$ & 0.000000 \\
\hline$D(\operatorname{LRent}(-1))$ & 0.071441 & & \\
\hline$D(\operatorname{LSIPrc}(-1))$ & $0.397854^{*}$ & $\operatorname{IntrRt}(-1)$ & $0.027277^{*}$ \\
\hline$D(\operatorname{IntrRt}(-1))$ & -0.004702 & $\operatorname{LInflRt}(-1)$ & $1.678986^{*}$ \\
\hline$D(\operatorname{LInflRt}(-1))$ & 1.226525 & $L G D P(-1)$ & -7.321507 \\
\hline$D(L G D P(-1))$ & -0.403462 & $\operatorname{LExcRt}(-1)$ & $0.624801^{*}$ \\
\hline$D(\operatorname{LExcRt}(-1))$ & -0.145122 & $\operatorname{LSSEmp}(-1)$ & $0.624801^{*}$ \\
\hline$D(\operatorname{LSSEmp}(-1))$ & 0.052748 & $@ \operatorname{TREND}(96 Q 1)$ & 0.0722222 \\
\hline C & 0.046847 & $C$ & 76.84792 \\
\hline D1 & -0.054512 & & \\
\hline$D 2$ & -0.003997 & & \\
\hline
\end{tabular}

Note. $*$ is significant at $5 \%$.

After accomplishing all of required test, further VECM estimation were carried out. The purpose was to analyze the interval (long-term and short-term) of the variables in the study (see Appendix D). Based on VECM estimate 
for rental rate in Table 1, a significant and positive long term correlation could be seen on the interest rates (IntrRt) and office rental rates (LRent). Other variables that positively and significantly related to the rental rate are inflation, exchange rate, service sector employment. In contrast, the economic growth adversely affects the rental rate and it has a negative sign. That phenomena is caused by the small contribution of the property sector to economic growth (GDP) and the range is still below 10 percent.

In other countries such as Hong Kong, Japan and South Korea, its property sector contribution to GDP has been above 20 percent, and even over 30 percent in the United States. Another possible reason for this problem is the use of average value of rent caused the change in GDP could not be followed by the change of rent rate.

In addition of being able to see the cointegration or long-term balance, the short-term relationship can also be observed through the VECM that can be seen in Table 1. The variable that significantly affect the rental rates in the short term is only selling price of the previous period. In the short term, it is proven that there is an adjustment mechanism from the short term to long term which is indicated by a significant and negative error cointegration with a value of -0.34 for rental rates. It means that the error is corrected at 0.34 percent for rental rates.

Based on VECM estimate for rental rate in Table 2, a significant and positive long term correlation could be seen on the interest rates (IntrRt) and office Selling Price (LSIPrc). Other variables that influence a positive and significant impact on the selling price are economic growth, the exchange rate and employment services sector. While for the inflation there is not enough evidence to say that there is a significant effect of inflation on the price of office. In this VECM estimation, Unemployment rate (UnEmp) was excluded because of data availability problems.

Table 2. VECM estimate for selling price

\begin{tabular}{|c|c|c|c|}
\hline \multicolumn{2}{|c|}{ Short Term } & \multicolumn{2}{|c|}{ Long Term } \\
\hline Variables & $\mathrm{D}($ LSIPrc $)$ & Variables & LSIPrc \\
\hline CointEq1 & $0.136515^{* *}$ & LRent(-1) & 0.000000 \\
\hline CointEq2 & $-0.515804 * *$ & $\operatorname{LSlPrc}(-1)$ & 1.000000 \\
\hline$D(\operatorname{LRent}(-1))$ & -0.044695 & & \\
\hline$D(\operatorname{LSIPrc}(-1))$ & $0.177916^{* *}$ & $\operatorname{IntrRt}(-1)$ & $0.006588^{*}$ \\
\hline$D(\operatorname{IntrRt}(-1))$ & $0.003366^{*}$ & $\operatorname{LInflRt}(-1)$ & 0.082370 \\
\hline$D(\operatorname{LInflRt}(-1))$ & $1.109136^{*}$ & $L G D P(-1)$ & $2.088162 *$ \\
\hline$D(L G D P(-1))$ & -0.568610 & $\operatorname{LExcRt}(-1)$ & $0.586150^{*}$ \\
\hline$D(\operatorname{LExcRt}(-1))$ & $0.185104 * *$ & $\operatorname{LSSEmp}(-1)$ & $0.302338^{*}$ \\
\hline$D(\operatorname{LSSEmp}(-1))$ & -0.231215 & @TREND(96Q1) & 0.0212465 \\
\hline C & $-0.436836^{* *}$ & C & -20.18506 \\
\hline$D 1$ & $0.490610^{* *}$ & & \\
\hline D2 & 0.000736 & & \\
\hline
\end{tabular}

Note. $* *$ and $*$ are significant at $5 \%$ and $10 \%$

In the short term, it is proven that there is an adjustment mechanism from the short term to long term which is indicated by a significant and negative error cointegration with a value of -0.52 for the sale price. It means that the error is corrected at 0.52 per cent for the selling price in each period.

\subsection{Analysis of Impulse Response Function (IRF) and FEVD for Rental Rate}

Analysis of impulse response function is to observe the response of dependent variable when it is getting shocked by independent variable at one standard deviation and that can be seen in Figure 5. Analysis result of IRF in rental rate variable againts shocks that given from interest rate was positively responded. This means that the impact from transmission process to the hikes of interest rate will be immediately visible. Normally, it is indicated by the increase in rental rates of office spaces. In addition, the rental rates will reach stability due to interest rates shocks in period of 17.

This result is consistent with the study conducted by Dobson and Goddard (1992) which states that the interest rate is positively related to the rental rates of all types of properties which have been studied, including office space. 

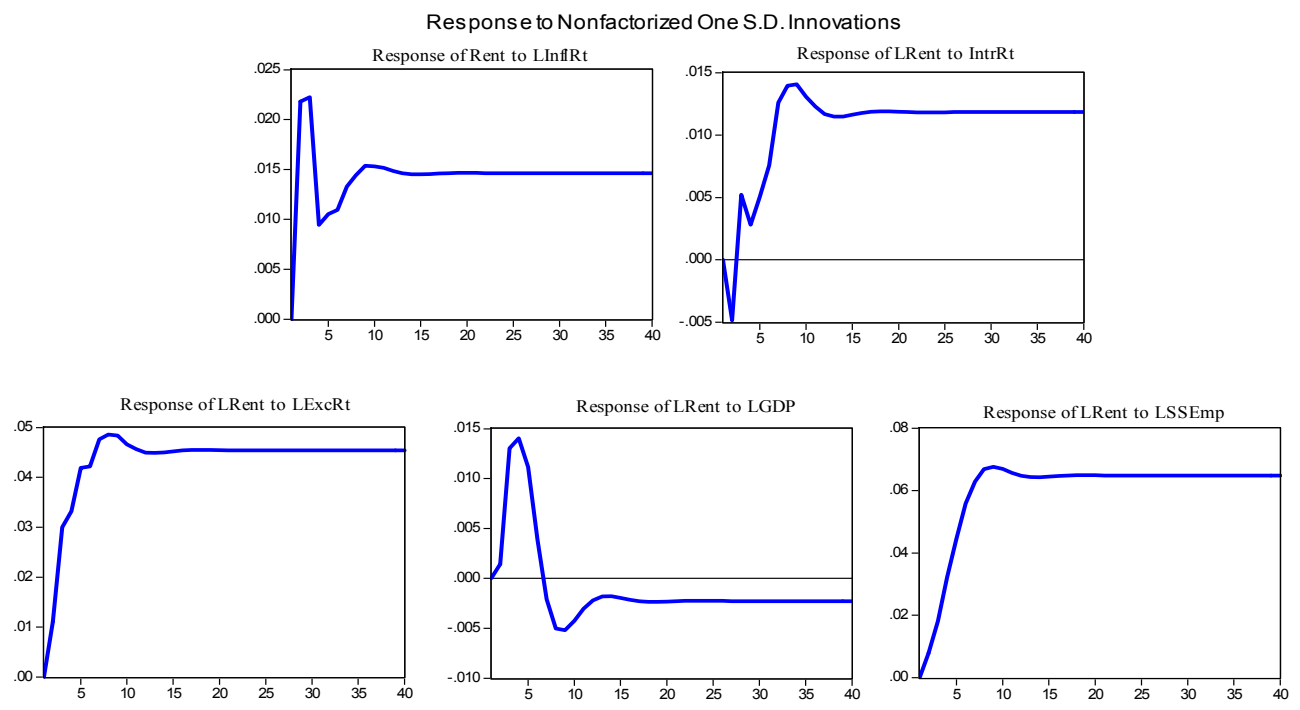

Figure 5. Response of LRent to LInflRt, IntrRt, LExcRt, LSSEmp and LGDP

The analysis of impulse response function (IRF) showed that the rental rate responded positively to the shocks that occur at one standard deviation in inflation. The rental rate reach stability in the period of 18 . Positive responses which are indicated by rental rate is not seemed to be appropriate with the research conducted by De Wit and Van Dijk (2003). Their study showed that the inflation has no effect on rental rates.

The analysis of impulse response function (IRF) showed that economic growth was responded negatively by office rental rates. It means that the rental rates are not sensitive to changes in economic growth due to the small contribution to GDP. This may indicate that the change in economic growth is not necessarily followed by the rise of office rental rates. The rental rate which is not sensitive to economic growth is not consistent with research that has been conducted by Ke and White (2008). One of their research results revealed that there is a significant positive relationship between economic growth (GDP) with a rental rate of office in Shanghai.

From the analysis of Impulse Response Function (IRF) the positive responses occured on rental rate variable against shocks of Service Sector Employment. This means that impact of the increase in service sector employment will soon to be seen regarding on the rising of rental rates of office space. Rental rates reach stability in the period of 20. Based on the results of the IRF mentioned above, it appears that the rental rates responded positively to the shocks that occurred in the employment service sector. This is consistent with the research conducted by NG and Higgins (2006) which suggests that employment services sector is a major determinant in explaining variations of office rental rates.

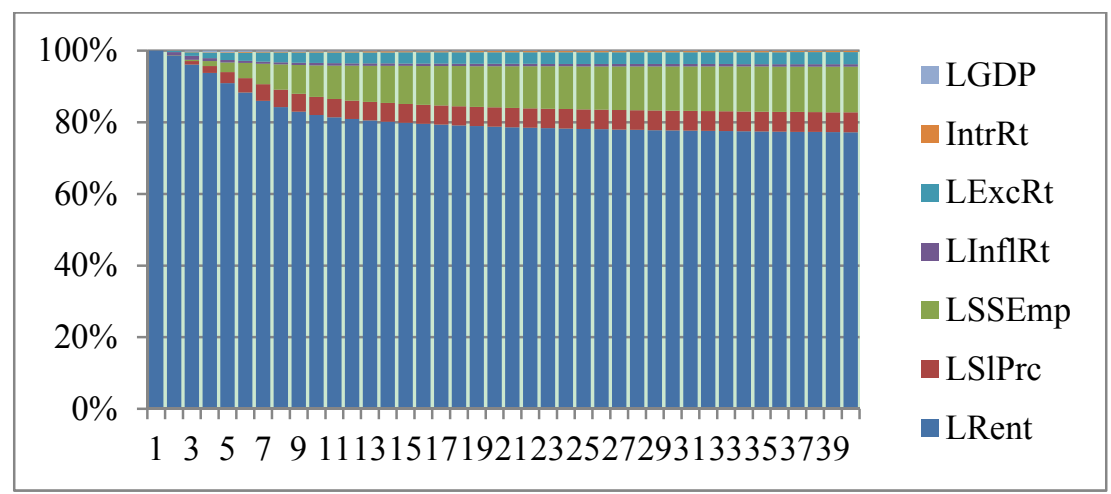

Figure 6. FEVD for rental rate (LRent)

From the analysis of IRF, the rental rates responded positively toward the shock of the exchange rate. Rental rates reach stability in the period of 20. This study is consistent with the research conducted by Ojetunde (2013) 
who in his research obtained the result that the exchange rate has a positive and significant relationship with rental rate.

Based on the analysis of FEVD that can be seen in Figure 6, the office rental rate are influenced by long-term or short term rental. The macroeconomic variables that being the most influence in the rental rate are employment services sector, followed by the exchange rate, inflation and interest rates. Economic growth seems not to have a direct influence on rental rates and this is indicated by a small value of decomposition variants. The amount of the contribution are vary, namely; rental rate is $77.23 \%$, selling prices $5.56 \%$, employment services sector $12.76 \%$, inflation $0.69 \%$, the exchange rate $\% 3.34$, interest rate $0.35 \%$ and economic growth $0.07 \%$, see Figure 6.

\subsection{Analysis of Impulse Response Function (IRF) and FEVD for Selling Price}

Analysis of Impulse Response Function (IRF) is used to observe the response of dependent variables when it is getting shocked by the independent variable at one standard deviation and that can be seen in Figure 7. Analysis result of the impulse response function in the selling price variable against shocks that given from interest rates variables was responded positively. This means that the impact from the transmission process to the hikes of interest rate will be immediately visible. Normally, it is indicated by the increase in the sale price of office spaces. In addition, the selling price will reach stability due to interest rates shocks in period of 20 . This study is consistent with the results of research conducted by Singh and Komal (2009) who stated that the interest rate can affect the selling price of real estate because interest rates will eventually affect the investors.

The analysis of impulse response function (IRF) showed that the sale price responded negatively to the shocks that occur at one standard deviation in inflation. That negative response showed inflation does not directly influence the selling price of office space. The selling price reaches stability in the period of 22 . Negative responses which were reflected by selling price variable are not seemed to be appropriate with the research conducted by De Wit and Van Dijk (2003). Their study showed that inflation has a positive and significant impact on selling price of office space.

From the analysis of Impulse Response Function (IRF) on the selling prices to the shocks that came from the economic growth, it seemed that the selling price variable responded positively due to economic growth. It takes 19 period (4 years) to achieve the stability on the price.
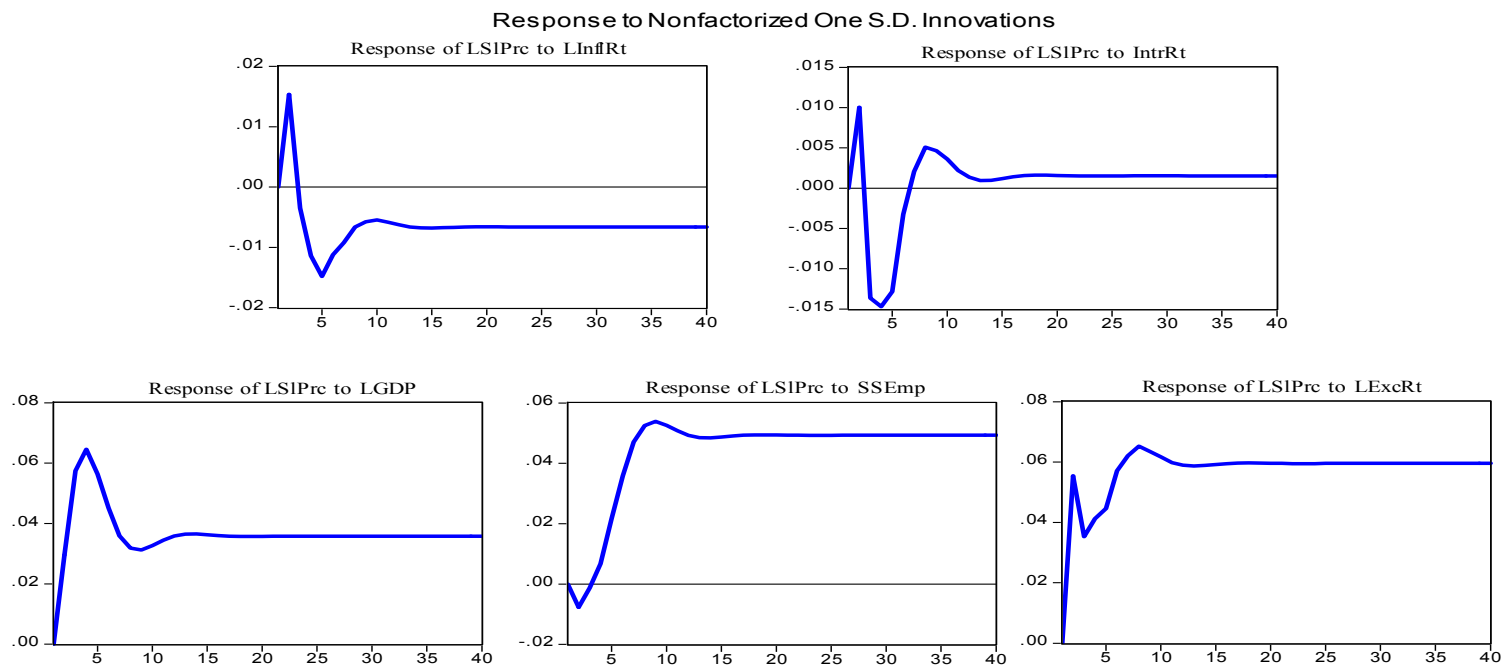

Figure 7. Response of LSIPrc to LInflRt, IntrRt, LExcRt, LSSEmp and LGDP

Positive effect that happened to sale price in connection with the shocks on economic growth is consistent with research conducted by De Wit and Van Dijk (2003), where economic growth has a positive relationship with the selling price of office.

From the analysis of Impulse Response Function (IRF) the positive responses occured on selling prices variable against shocks of Service Sector Employment. This means that the impact of the increase in service sector employment will soon to be seen regarding on the rising of selling prices of office space. Selling price reaches 
stability condition in the period of 22. This study is consistent with the research conducted Apergis (2003) who mentions that the macroeconomic variables (including labor) has considerable influence on the price of real estate.

From the analysis of IRF, selling prices responded positively toward the shock of the exchange rate. The selling price reached stability in period of 24. This study is consistent with the study conducted by Shaifulfazlee (2012) who mentioned in his findings that exchange rate affects the price of the property.

Based on the FEVD of the selling price, the rental rates have a great effect on the selling price. The greater the rental rates, the greater the selling price can be expected. Macroeconomic variables that have most influence on the selling price is the employment services sector, the exchange rate and economic growth. The inflation and interest rates also affect the sale price, but the effect is not as big as other variables. The amount of the contribution to the selling price is vary, namely, rental rate by $45 \%$, the selling price by $2.71 \%$, the employment service sector by $20.06 \%$, inflation by $1.96 \%$, the exchange rate by $17.91 \%$, interest rate by $1.1 \%$ and economic growth by $11.18 \%$, see Figure 8 .

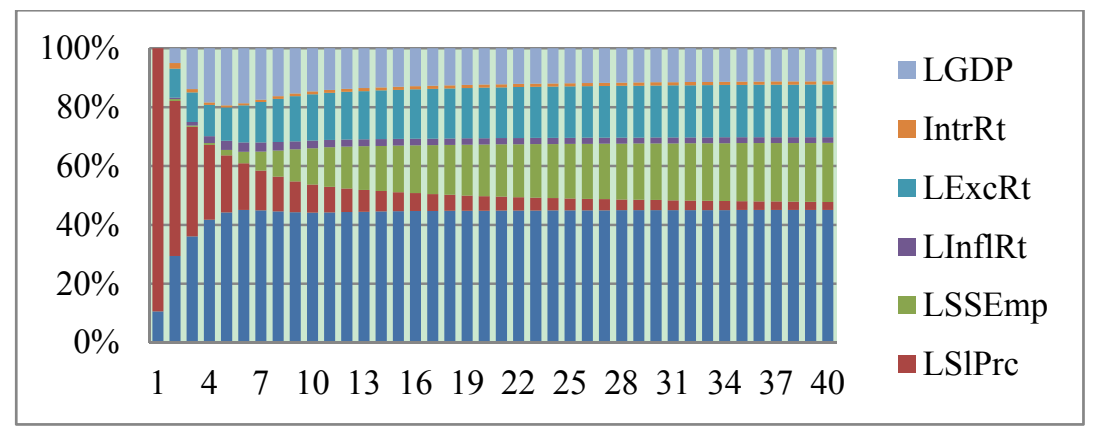

Figure 8. FEVD For selling price (LSIPrc)

\section{Managerial Implications}

The results showed that the macroeconomic variables in this study had an influence on the formation of selling prices and rental rates for office space. The developers, investors, and others can use this research as one of the tools in the study of their work. This research result would help in providing information regarding the movements of macroeconomic variables that may influence decision in determining rental rate and selling price of office space building.

A good comprehension about macroeconomic variables would turn the investment project into profit. Failure in understanding the movements of macroeconomic variables will bring about misleading interpretation. Consequently, the stipulated rental rate and selling price will not represent true values. If this thing happens, the invesment project in commercial property may go into a bankruptcy.

\section{Conclusions and Recommendations}

Based on the estimation of VECM, there is a long-term equilibrium and short term relationships between macroeconomic variables regarding with rental rates and selling prices of the office space. Results of IRF shows that rental rates responded positively to variables of interest rates, inflation, exchange rate and employment services sector. The economic growth seems not to have a direct influence on rental rates. Conversely, positive response on the selling price occurred in interest rates, exchange rates, economic growth and employment services sector. While inflation seems not to have a direct impact on the selling price of office. The rental rates appear more quickly to be stable after the shock of macroeconomic variables compared to selling price.

At variance decomposition structure, office rental rates are predominantly influenced by the rental rate itself followed by the employment services sector, selling price, exchange rate, inflation, interest rates and economic growth. Whereas the sale price is predominantly influenced by the rental rate, employment services sector, the exchange rate, economic growth, prices, inflation and interest rates. Interesting phenomenon is in the employment services sector which being the most dominant variable affecting selling prices and office rental rates compared with other macroeconomic variables.

Furthermore, research on macroeconomic factors and their influence on each class of office building such as $\mathrm{A}^{\prime}$, $\mathrm{A}, \mathrm{B}$ and $\mathrm{C}$, are expected can be done in the future, in an effort to have clearer insight and overview. 


\section{References}

Ajayi, R. A., \& Mougoue, M. (1996). On the Dynamic Relation between Stock Prices and Exchange Rates. The Journal of Financial Research, 19, 93-207.

Apergis, N. (2003). Housing Prices and Macroeconomi Factors: Prospect Within the European Monetary Union. International Real Estate Review, 6(1), 63-74.

Brounen, D., \& Jennen, M. (2009). Asymmetric Properties of Office Rent Adjustment. Journal of Real Estate Finance \& Economics, 39, 336-358.

Chalermpong, S., \& Wattana, K. (2009). Rent Capitalization of Access to Rail Transit Stations: Spatial Hedonic Models of Office Rent in Bangkok. Journal of the East. Asia Society for Transp Studies, 8.

Chin, W. (2003). Macro-economic Factors Affecting Office Rental Values in Southeast Asian Cities: The Case of Singapore, Hongkong, Taipei, Kuala Lumpur, and Bangkok. Oxford Brookes University, paper presented at 2003 PRRES Conference, Australia, Brisbane.

D’Arcy, E., McGough, T., \& Tsolacos, S. (1999). An Econometric Analysisof the Office Rental Cyclein The Dublin Area. Journal of Property Research, 16(1), 309-321.

De Wit, I., \& Van Dijk, R. (2003). The Global Determinants of Direct Office Real Estate Returns. Journal of Real Estate Finance \& Economics, 26, 27-45.

Dimitrova, D. (2005). The Relationship Between Exchange Rates and Stock Prices: Studied in a Multivariate Model. Issues in Political Economy, 14, 1-25.

Dobson, S. M., \& Goddard, J. A. (1992). The Determinants of Commercial Property Prices and Rents. Bulletin of Economic Research, 44(4), 301-321.

Ke, Q., \& White, M. (2009). An Econometric Analysis of Shanghai Office Rents. Journal of Property Investment \& Finance, 27(2), 120-139.

Kurzrock, B. M., Rottke, N. B., \& Schiereck, D. (2009). Factors That Influence the Performance of Office Properties. Journal of Real Estate Portfolio Management, 15(1), 59-73.

Ng, B. F., \& Higgins, D. (2006). Modelling The Commercial Property Market: An Empirical Study of The Singapore Office Market. Pacific Rim Property Research Journal, 13(2), 176-193.

Ojetunde, I. (2013). Revisiting the Interaction between the Nigerian Property Market and the Macroeconomy. FIG Working Week 2013, Nigeria.

Oven, V. A., \& Pekdemir, D. (2006). Office Rent Determinants Utilising Factor Analysis-A Case Study for Istanbul. Journal of Real Estate Finance \& Economics, 33, 51-73.

Peng, W., Tam, D., \& Yiu, M. S. (2005). The Property Market and the Macroeconomy of the Mainland: A Cross Region Study. Hongkong Institute for Monetary Research.

Property Report. (2009). Jakarta Real Estate: Jakarta's Office Rents Increase Whilst Demand Decrease. The Trusted Source for Real Estate News.

Prudence LWT. (2007). An Empirical Study of Globalization and Macroeconomic Influence on Office Rents in Hongkong. Hongkong, Faculty of Architecture, University of Hongkong.

Shaifulfazlee, M. (2012). Causality Between Property Price and Macroeconomic Variables: An Application of Vector Error Correction and Variance Decomposition Methods to Malaysia. Academia-Edu, 1-25.

Shing, V., \& Komal. (2009). Prospects and Problems of Real Estate in India. International Research Journal of Finance and Economics, 24.

Slade, B. A. (2000). Office Rent Determination During Market Decline and Recovary. Journal of Real Estate Research, 20(2), 357-380.

Thrall, G. I. (2002). Business Geography and New Real Estat Market Analysis: Spatial Information System. New York: Oxford University Press, Inc.

Tsolakos, S., Keogh, G., \& McGough. (1998). Modelling Use, Investment, and Development in the British Office Market. Environment and Planning A, 30(8), 1409-1427.

Voigtlander, M. (2011). The Link Between the Office Market and Labor Market in Germany. Germany, Cologne: Institut der deutschen Wirtschaft Koln. 
Ward, B. D., \& Siregar, H. (2000). The Role of Aggregate Demand Shocks in Explaining Indonesian Macroeconomic Fluctuations. Commerce Division Discussion Paper, No. 86, Lincoln University.

Xiaoguang, W., \& Xiuzhing, Z. (2006). The Analysis: the Influence of RMB Exchange Rate Fluctuation on Real Estate Price in China. Department of Land \& Real Estate Management, School of Public Administration.

\section{Appendix A. Unit Root Test for Level and First Difference Table}

\begin{tabular}{clcccccc}
\hline \multirow{2}{*}{ No } & \multirow{2}{*}{ Variables } & \multicolumn{3}{c}{ Level } & \multicolumn{3}{c}{ first difference } \\
\cline { 3 - 7 } & & \# of lag & ADF test & Explanation & \# of lag & ADF test & Explanation \\
\hline 1 & LRent & 0 & -1.719881 & Not Stasionary & 1 & $-5.799055^{* * *}$ & Stasionary \\
2 & LSlPrc & 3 & -2.881717 & Not Stasionary & 2 & $-5.732418^{* * *}$ & Stasionary \\
3 & IntrRt & 10 & $-12.50375^{* * *}$ & Stasionary & 4 & $-5.208302^{* * *}$ & Stasionary \\
4 & LInflRt & 0 & -1.751976 & Not Stasionary & 1 & $-8.304637^{* * *}$ & Stasionary \\
5 & LGDP & 6 & 1.445536 & Not Stasionary & 6 & $-3.785711^{* *}$ & Stasionary \\
6 & LSSEmp & 1 & 0.049341 & Not Stasionary & 0 & $-3.857514^{* * *}$ & Stasionary \\
7 & UnEmp & 3 & -0.225950 & Not Stasionary & 2 & $-2.628542^{* * *}$ & Stasionary \\
8 & LExcRt & 1 & 0.705681 & Not Stasionary & 0 & $-6.706577^{* * *}$ & Stasionary \\
\hline
\end{tabular}

Note. $*$, ** and $* * *$ Significant at $10 \%, 5 \%$ and $1 \%$.

\section{Appendix B}

Table B1. VAR stability condition check

\begin{tabular}{ll}
\hline Root & Modulus \\
\hline 0.995204 & 0.995204 \\
0.958490 & 0.958490 \\
0.676887 & 0.676887 \\
$0.551032-0.358327 \mathrm{i}$ & 0.657293 \\
$0.551032+0.358327 \mathrm{i}$ & 0.657293 \\
0.543003 & 0.543003 \\
0.048845 & 0.048845 \\
\hline
\end{tabular}

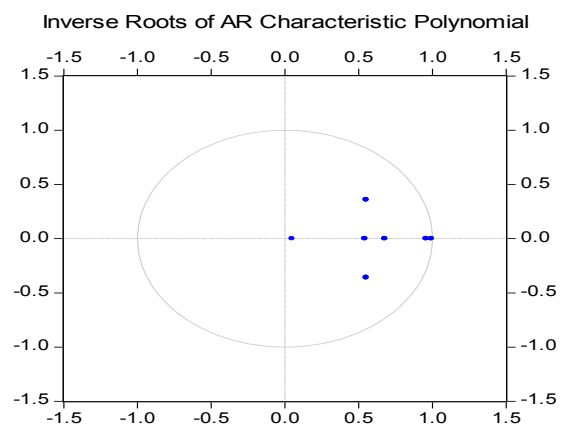

Figure B1. Unit root test

\section{Appendix C}

Table C1. Optimum lag length

\begin{tabular}{ccccccc}
\hline Lag & LogL & LR & FPE & AIC & SC & HQ \\
\hline 0 & 81.03851 & NA & $3.72 \mathrm{e}-10$ & -1.847339 & -1.144844 & -1.570160 \\
1 & 480.3737 & 675.7981 & $7.88 \mathrm{e}-15$ & -12.62688 & $-10.28524^{*}$ & -11.70295 \\
2 & 562.7312 & $121.6356^{*}$ & $3.03 \mathrm{e}-15^{*}$ & -13.65327 & -9.672466 & $-12.08259^{*}$ \\
3 & 614.8727 & 65.77848 & $3.25 \mathrm{e}-15$ & $-13.74993^{*}$ & -8.129973 & -11.53250 \\
\hline
\end{tabular}


Table C2. Cointegration test

\begin{tabular}{lccccc}
\hline No of CE (s) & Eigenvalue & Trace statistics & Critical Value (0.05) & Max-eigen statistics & Critical alue (0.05) \\
\hline $\mathrm{r}=0^{*}$ & 0.695838 & $226.3603^{*}$ & 150.5585 & $78.55294^{*}$ & 50.59985 \\
$\mathrm{r}=1^{*}$ & 0.565707 & $147.8074^{*}$ & 117.7082 & $55.04631^{*}$ & 44.49720 \\
$\mathrm{r}=2^{*}$ & 0.391382 & $92.76108^{*}$ & 88.80380 & 32.77324 & 38.33101 \\
$\mathrm{r}=3$ & 0.342194 & 59.98784 & 63.87610 & 27.64382 & 32.11832 \\
$\mathrm{r}=4$ & 0.271294 & 32.34402 & 42.91525 & 20.88802 & 25.82321 \\
$\mathrm{r}=5$ & 0.157246 & 11.45600 & 25.87211 & 11.29128 & 19.38704 \\
$\mathrm{r}=6$ & 0.002493 & 0.164720 & 12.51798 & 0.164720 & 12.51798 \\
\hline
\end{tabular}

Note. ${ }^{*}$ is significant at $5 \%$.

\section{Appendix D. VECM Output Table}

Vector Error Correction Estimates

Date: 11/06/14 Time: 16:28

Sample (adjusted): 1996Q3 2012Q4

Included observations: 66 after adjustments

Standard errors in ( ) \& t-statistics in [ ]

\begin{tabular}{|c|c|c|c|c|c|c|c|}
\hline Cointegrating Eq: & CointEq1 & CointEq2 & & & & & \\
\hline LRent(-1) & 1.000000 & 0.000000 & & & & & \\
\hline LSIPrc(-1) & 0.000000 & 1.000000 & & & & & \\
\hline \multirow[t]{3}{*}{ LInflRt(-1) } & -1.678986 & -0.082370 & & & & & \\
\hline & $(0.71240)$ & $(0.37945)$ & & & & & \\
\hline & {$[-2.35681]$} & {$[-0.21708]$} & & & & & \\
\hline \multirow[t]{3}{*}{ IntrRt(-1) } & -0.027277 & -0.006588 & & & & & \\
\hline & $(0.00455)$ & $(0.00242)$ & & & & & \\
\hline & {$[-6.00112]$} & {$[-2.72115]$} & & & & & \\
\hline \multirow[t]{3}{*}{ LExcRt(-1) } & -0.624801 & -0.586150 & & & & & \\
\hline & $(0.31800)$ & $(0.16938)$ & & & & & \\
\hline & {$[-1.96478]$} & {$[-3.46058]$} & & & & & \\
\hline \multirow[t]{3}{*}{ LGDP(-1) } & 7.321507 & -2.088162 & & & & & \\
\hline & $(1.34911)$ & $(0.71859)$ & & & & & \\
\hline & {$[5.42693]$} & {$[-2.90593]$} & & & & & \\
\hline \multirow[t]{3}{*}{$\operatorname{LSSEmp}(-1)$} & -0.778222 & -0.302338 & & & & & \\
\hline & $(0.23380)$ & $(0.12453)$ & & & & & \\
\hline & {$[-3.32864]$} & {$[-2.42785]$} & & & & & \\
\hline \multirow[t]{3}{*}{ @TREND(96Q1) } & -0.072222 & 0.021246 & & & & & \\
\hline & $(0.02699)$ & $(0.01438)$ & & & & & \\
\hline & {$[-2.67559]$} & {$[1.47770]$} & & & & & \\
\hline $\mathrm{C}$ & -76.84792 & 20.18506 & & & & & \\
\hline Error Correction: & $\mathrm{D}$ (LRent) & D(LSIPrc) & D(InflRt) & IntrRt & $\mathrm{D}($ LExcRt $)$ & D(LGDP) & D(LSSEmp) \\
\hline \multirow[t]{3}{*}{ CointEq1 } & -0.034423 & 0.136515 & 0.004995 & 0.654532 & 0.309650 & -0.052972 & -0.004575 \\
\hline & $(0.05700)$ & $(0.03428)$ & $(0.00772)$ & $(1.53686)$ & $(0.06411)$ & $(0.00910)$ & (0.01969) \\
\hline & {$[-0.60391]$} & [ 3.98284$]$ & {$[0.64664]$} & {$[0.42589]$} & [ 4.82995] & {$[-5.82175]$} & {$[-0.23228]$} \\
\hline \multirow[t]{3}{*}{ CointEq2 } & -0.348427 & -0.515804 & 0.002051 & -8.636264 & 0.166071 & -0.027868 & 0.018551 \\
\hline & $(0.13914)$ & $(0.08367)$ & $(0.01885)$ & $(3.75156)$ & $(0.15650)$ & $(0.02221)$ & $(0.04808)$ \\
\hline & {$[-2.50413]$} & {$[-6.16483]$} & {$[0.10877]$} & {$[-2.30205]$} & [ 1.06118$]$ & {$[-1.25467]$} & {$[0.38587]$} \\
\hline \multirow[t]{3}{*}{$\mathrm{D}(\operatorname{LRent}(-1))$} & 0.071441 & -0.044695 & -0.048700 & -9.802502 & 0.249102 & 0.057534 & 0.066549 \\
\hline & $(0.15502)$ & $(0.09322)$ & $(0.02101)$ & $(4.17974)$ & $(0.17436)$ & $(0.02475)$ & $(0.05356)$ \\
\hline & {$[0.46085]$} & {$[-0.47946]$} & {$[-2.31832]$} & {$[-2.34524]$} & [ 1.42868$]$ & [ 2.32498] & [ 1.24245$]$ \\
\hline \multirow[t]{3}{*}{$\mathrm{D}(\operatorname{LSIPrc}(-1))$} & 0.397854 & 0.177916 & 0.021771 & 26.07321 & -0.025662 & 0.015922 & -0.056441 \\
\hline & $(0.18325)$ & (0.11019) & $(0.02483)$ & $(4.94086)$ & $(0.20611)$ & $(0.02925)$ & $(0.06332)$ \\
\hline & [ 2.17109$]$ & [ 1.61458$]$ & {$[0.87675]$} & [ 5.27705] & {$[-0.12451]$} & [ 0.54429] & {$[-0.89142]$} \\
\hline \multirow[t]{2}{*}{ D(LInflRt(-1)) } & 1.226525 & 1.109136 & -0.188754 & -66.24295 & 1.729267 & -0.685840 & -0.256778 \\
\hline & $(0.98131)$ & $(0.59009)$ & $(0.13297)$ & $(26.4583)$ & $(1.10371)$ & $(0.15665)$ & $(0.33906)$ \\
\hline
\end{tabular}




\begin{tabular}{|c|c|c|c|c|c|c|c|}
\hline & [1.24989] & {$[1.87962]$} & {$[-1.41949]$} & {$[-2.50367]$} & {$[1.56677]$} & {$[-4.37826]$} & {$[-0.75733]$} \\
\hline \multirow[t]{3}{*}{$\mathrm{D}(\operatorname{IntrRt}(-1))$} & -0.004702 & 0.003366 & 0.000979 & -0.035318 & -0.008044 & -0.001209 & $8.75 \mathrm{E}-05$ \\
\hline & $(0.00339)$ & $(0.00204)$ & $(0.00046)$ & $(0.09130)$ & $(0.00381)$ & $(0.00054)$ & $(0.00117)$ \\
\hline & {$[-1.38842]$} & [ 1.65298$]$ & [ 2.13332] & {$[-0.38682]$} & {$[-2.11200]$} & {$[-2.23716]$} & {$[0.07482]$} \\
\hline \multirow[t]{3}{*}{ D(LExcRt-1)) } & -0.145122 & 0.185104 & -0.029496 & 9.332165 & -0.270955 & -0.063200 & 0.006073 \\
\hline & $(0.13333)$ & $(0.08018)$ & $(0.01807)$ & (3.59497) & $(0.14996)$ & $(0.02128)$ & $(0.04607)$ \\
\hline & {$[-1.08842]$} & [ 2.30870] & {$[-1.63255]$} & [ 2.59590] & {$[-1.80680]$} & {$[-2.96939]$} & [ 0.13183$]$ \\
\hline \multirow[t]{3}{*}{$\mathrm{D}(\operatorname{LGDP}(-1))$} & -0.403462 & -0.568610 & -0.084707 & -31.66853 & 0.088772 & -0.267194 & -0.044045 \\
\hline & $(0.71930)$ & $(0.43253)$ & $(0.09747)$ & (19.3939) & $(0.80902)$ & $(0.11482)$ & $(0.24853)$ \\
\hline & {$[-0.56091]$} & {$[-1.31461]$} & {$[-0.86906]$} & {$[-1.63291]$} & [ 0.10973$]$ & {$[-2.32703]$} & {$[-0.17722]$} \\
\hline \multirow[t]{3}{*}{ D(LSSEmp(-1)) } & 0.052748 & -0.231215 & 0.008290 & -1.897821 & 0.464466 & -0.022799 & 0.501689 \\
\hline & $(0.36644)$ & $(0.22035)$ & $(0.04966)$ & $(9.88013)$ & $(0.41215)$ & $(0.05850)$ & $(0.12661)$ \\
\hline & [0.14395] & {$[-1.04930]$} & [0.16695] & {$[-0.19208]$} & [ 1.12693$]$ & {$[-0.38976]$} & [3.96245] \\
\hline \multirow[t]{3}{*}{$\mathrm{C}$} & 0.046847 & -0.436836 & 0.008872 & -3.967751 & -0.584696 & 0.149054 & 0.015197 \\
\hline & $(0.14324)$ & $(0.08613)$ & $(0.01941)$ & $(3.86200)$ & $(0.16110)$ & $(0.02286)$ & $(0.04949)$ \\
\hline & {$[0.32706]$} & {$[-5.07170]$} & {$[0.45708]$} & {$[-1.02738]$} & {$[-3.62931]$} & [ 6.51887] & {$[0.30706]$} \\
\hline \multirow[t]{3}{*}{ D1 } & -0.054512 & 0.490610 & 0.021749 & 5.632784 & 0.627415 & -0.139008 & -0.001850 \\
\hline & $(0.16027)$ & $(0.09638)$ & $(0.02172)$ & (4.32138) & $(0.18027)$ & $(0.02558)$ & $(0.05538)$ \\
\hline & {$[-0.34012]$} & [ 5.09052] & [ 1.00141$]$ & {$[1.30347]$} & [ 3.48048$]$ & {$[-5.43325]$} & {$[-0.03341]$} \\
\hline \multirow[t]{3}{*}{ D2 } & -0.003997 & 0.000736 & -0.016848 & -1.006447 & -0.022365 & 0.004495 & 0.007198 \\
\hline & $(0.03620)$ & $(0.02177)$ & $(0.00490)$ & $(0.97595)$ & $(0.04071)$ & $(0.00578)$ & $(0.01251)$ \\
\hline & {$[-0.11043]$} & {$[0.03381]$} & {$[-3.43502]$} & {$[-1.03125]$} & {$[-0.54935]$} & {$[0.77800]$} & {$[0.57554]$} \\
\hline R-squared & 0.247498 & 0.812784 & 0.417057 & 0.776074 & 0.452530 & 0.652875 & 0.348403 \\
\hline Adj. R-squared & 0.094210 & 0.774647 & 0.298309 & 0.730459 & 0.341009 & 0.582165 & 0.215670 \\
\hline Sum sq. resids & 0.810791 & 0.293176 & 0.014888 & 589.4188 & 1.025678 & 0.020661 & 0.096792 \\
\hline S.E. equation & 0.122534 & 0.073683 & 0.016604 & 3.303810 & 0.137819 & 0.019560 & 0.042337 \\
\hline F-statistic & 1.614598 & 21.31243 & 3.512126 & 17.01372 & 4.057781 & 9.233062 & 2.624845 \\
\hline Log likelihood & 51.53027 & 85.09908 & 183.4468 & -165.9029 & 43.77200 & 172.6331 & 121.6698 \\
\hline Akaike AIC & -1.197887 & -2.215124 & -5.195359 & 5.390996 & -0.962788 & -4.867670 & -3.323327 \\
\hline Schwarz SC & -0.799768 & -1.817005 & -4.797240 & 5.789115 & -0.564669 & -4.469551 & -2.925208 \\
\hline Mean dependent & 0.024051 & 0.025543 & 0.018078 & -0.106061 & 0.021394 & 0.009220 & 0.021738 \\
\hline S.D. dependent & 0.128749 & 0.155216 & 0.019822 & 6.363601 & 0.169773 & 0.030260 & 0.047805 \\
\hline \multicolumn{2}{|c|}{ Determinant resid covariance (dof adj.) } & $8.65 \mathrm{E}-16$ & & & & & \\
\hline \multicolumn{2}{|c|}{ Determinant resid covariance } & $2.12 \mathrm{E}-16$ & & & & & \\
\hline \multicolumn{2}{|l|}{ Log likelihood } & 535.3884 & & & & & \\
\hline \multicolumn{2}{|c|}{ Akaike information criterion } & -13.19359 & & & & & \\
\hline \multicolumn{2}{|l|}{ Schwarz criterion } & -9.875928 & & & & & \\
\hline
\end{tabular}

\section{Copyrights}

Copyright for this article is retained by the author(s), with first publication rights granted to the journal.

This is an open-access article distributed under the terms and conditions of the Creative Commons Attribution license (http://creativecommons.org/licenses/by/3.0/). 